\title{
The Role of Naturally Regenerated Acacia Forests on Birds Population in UMS Campus, Sabah
}

\author{
J, Sompud ${ }^{1}$, EA, Gilbert ${ }^{1}, \mathrm{C}$, Boon $^{2}$, and H, Affendy ${ }^{1}$ \\ ${ }^{1}$ Faculty of Science and Natural Resources, Universiti Malaysia Sabah, Jalan UMS, 88400 Kota \\ Kinabalu, Sabah, Malaysia. \\ ${ }^{2}$ Wildlife Sentinels, Jalan Kolombong, Inanam, 88450, Kota Kinabalu, Sabah
}

\begin{abstract}
Acacia species was introduced as the commercial species in Sabah for the production of pulp and paper. This species is able to naturally regenerate and spreads widely including inside the UMS campus giving its ability to survive in degraded lands. However, there is still limited study that has been done to determine whether the regenerated Acacia trees can support biodiversity using birds as bio-indicator. Hence, this study was conducted to investigate the status of the birds inside the UMS campus. Two types of forests were chosen namely the Naturally Regenerated Acacia Forest (NRAF) and Forest Dominated with Indigenous Species trees (FDIST). The methods that were applied were solely mistnetting and ring banding. Data were analysed using Shannon-Wiener index, Diversity t-test as well as Mann-Whitney U test. The results show that there were no significant difference of bird diversity and abundance between both forests. The study shows that NRAF does play a role in sustaining the bird population in UMS campus and it is recommended that NRAF should be conserve for edu-tourism but also for research purposes.
\end{abstract}

Keywords: Acacia forest, Bird diversity, Bird abundance, Understory bird, Avian population.

\section{INTRODUCTION}

Forest contains a complex structure that relates to the flora and fauna in the ecosystem. However, the conversion of forest lands into plantation and agriculture areas had increased throughout the years, especially in Borneo (Azman et. al., 2011). Exotic species such as Acacia mangium was introduced and had become dominant industrial species planted in Southeast Asia (Sheldon et. al., 2010). A. mangium has been introduced to Sabah in 1966 from Queensland, Australia (Udarde \& Hepburn, 1987). This species was initially brought to Sabah as a species for firebreaks (Udarde \& Hepburn, 1987) but now it has developed into a forest plantation tree that is widely planted for pulp and paper production.

Acacia sp. is a very resilient tree that can inhabits terrain barren land with poor soil. The study that was conducted by Thomas \& Kent (1987) in Sabah shows $A$. mangium adaptability in arid, poor soil, and degraded land. In Sabah, the opening of forest lands has been performed to make way for development that created human modified forests. Acacia trees that have naturally regenerated can be commonly throughout Sabah that form patches of forests existing in various sizes. Human development activities affect the biodiversity of the previous habitat as noted by Hartley, (2002).

Birds have a distinct relationship with their surrounding environment. Lambert \& Collar (2002) stated that there are about more than 300 species of birds found in the Borneo Island. Apart from being the pollinator and seed dispersal (Peh et. al., 2005; Clearly et al., 2007), it is also a good environmental indicator of the biodiversity of a

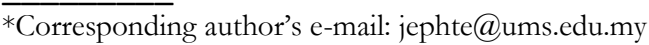


particular habitat (Sodhi et. al., 2005). According to (Yap et. al., 2007), it is often selected due to its' high sensitivity in detecting changes that occur in its habitat. This can be seen through the changes in the diversity of the bird population (Zakaria et. al., 2005).

Published information about bird population in Naturally Regenerated Acacia Forest (NRAF) is still lacking. The study of bird population in forest plantation dominated with exotic species can provide crucial information about the occurrence and distribution of the birds in those areas (Styring et. al., 2011). The lack of published literatures on the capability NRAF to support biodiversity has raised the concern upon the effect of these species towards the environment. Therefore, the aim of this study was to identify the role of the NRAF towards biodiversity by documenting the bird population in the NRAF and Forest Dominated with Indigenous Species Trees (FDIST) inside the Universiti Malaysia Sabah campus. The null hypothesis of the study is that the bird diversity and abundance are lower in NRAF as opposed to FDIST.

\section{MATERIALS AND METHODS}

Universiti Malaysia Sabah was established in 1994. At the main campus, most of the forested areas were cleared to allow for built environment except for those at UMS hill. For the purpose of this study, the existing forest was categorised into two, namely, NRAF and FDIST. NRAF was dominated with Acacia $s p$. The highest species found in NRAF of UMS Campus was the Acacia sp. that consisted of about $80 \%$ from the total standing trees in that area (Sompud et. al., 2014). Other species of trees such as Eleocarpus sp. and Syzgium sp. can be found there but occurring at less than $5 \%$ only. The FDIST in UMS campus were situated around the UMS hill. The tree species of indigenous origin consists of about $70 \%$ of the total standing trees. In terms of the total forest coverage in UMS Campus, the NRAF covers about $37.5 \%$ and the FDIST covers approximately about $62.5 \%$.

The NRAF areas inside the campus consisted patches of Acacia forest islands that were located mainly at Faculty of Food Science and Nutrition (SSMP), Arboretum Forestry Complex and Outdoor Development Education Centre (ODEC) (Figure 1). The study stations for FDIST were at UMS Peak, UMS Waterfall and around the UMS hill.

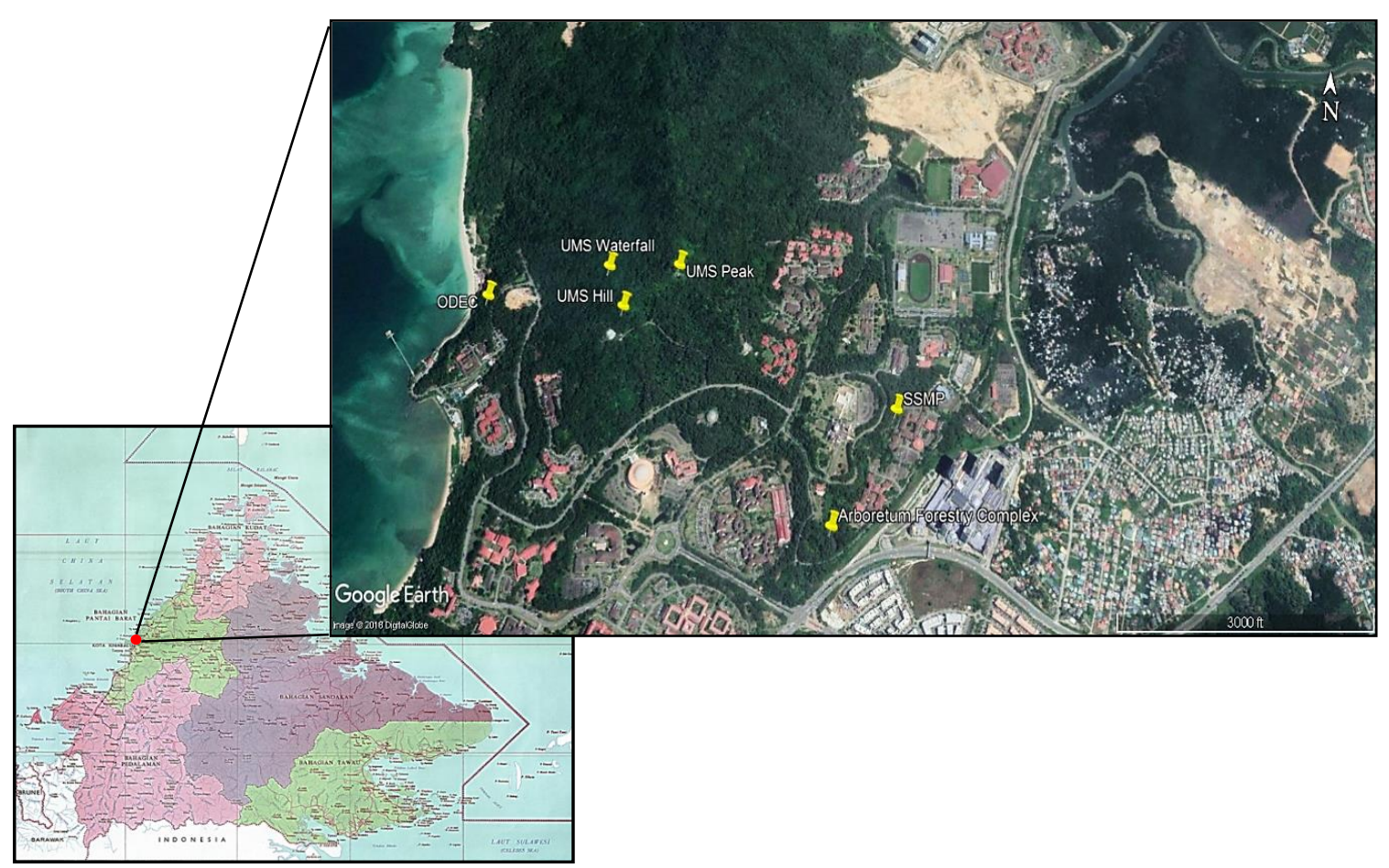

Figure 1. The study stations in UMS Campus were shown in highlighted yellow colour. (Source: Director of National Mapping Malaysia 1983 and Google earth, 2015). 
The data collection using mist nets was initiated in May 2014. Mist-netting is a standard method that was used to capture understory birds (Edwards et. al., 2009). These nets were installed for at least 21 days at the distance of 50 to 100-meter interval by adopting the standard method done by (Zakaria et. al., 2005). The mist nets were set up for three consecutive days and were opened from 6.ooam until 5.oopm in order to maximize the number of captures. Apart from that, the nets were checked for every one-hour interval to increase the number of captured (Loiselle \& Blake, 1999). The bird captured were identified and measured by using two field guidebooks documented by (Phillips \& Phillips, 2011) and (Wong, 2012). After that, they were then tagged with a metal ring band based on the standard method.

The data analysis was conducted by using the descriptive analysis. Diversity indices of Simpson diversity index (1-D) and Shannon-Weiner diversity indices were calculated (Magurran, 2004). Diversity t-test using PAST software was used to determine if there was significant difference between the Shannon diversity index between NRAF and FDIST. Man-Whitney $U$ test was used to compare the means of the bird caught in NRAF and FDIST.

\section{RESULTS AND DISCUSSIONS}

A total of 161 individuals from 34 species and 7 family of understory bird were captured in both NRAF and FDIST inside the UMS campus. The Shannon diversity index shows that both NRAF has and FDIST has diverse understory bird population $(\mathrm{H}=2.79$ and $\mathrm{H}=2.52)$. Apart from that, the value of the Simpson Diversity Index (1-D) was slightly higher in NRAF with 0.921 as opposed to FDIST with o.884. However, the Diversity t-test analysis shows that there was no significant difference of the bird population between these two types of forests $(t=1.7715$; $\mathrm{df}=$ 1423.53; $\mathrm{p}=0.079$ ).

NRAF recorded 89 individuals captured and FDIST recorded 72 individuals. Mann-Whitney $U$ test was performed to compare between the number of birds caught in NRAF and FDIST. The result shows that there was no significant difference between the number of birds captured in NRAF and FDIST $(\mathrm{U}=302 ; \mathrm{z}=-0.50 ; \mathrm{p}=0.960)$.

Table 1 showed that both type of forests was dominated by species from the Pycnonotidae family with $24 \%$ relative abundance in NRAF and 50\% in FDIST. The second highest number of individuals recorded in NRAF come from the
Alcedinidae family with 13 individuals captured followed by the Columbidae family with 11 individuals recorded. In contrast, the Timaliidae family was the second most abundance in FDIST with 7 individuals recorded followed by the Alcedinidae with 6 individuals captured. Families of understory birds such as Alauididae, Campephagidae, Caprimulgidae, Cisticolidae, Dicaeidae and Hirundinidae were present in NRAF but were not found in FDIST. Meanwhile, Aegithinidae, Laniidae, Pachycephalidae, Rhampastidae and Strigidae families were only recorded in FDIST.

According to the 24 species of birds recorded in NRAF, the Yellow-vented Bulbul (Pycnonotus goiavier) was found to be the highest with $15.73 \%$ of relative abundance followed by Zebra Dove (Geopelia striata) and Collared Kingfisher (Todiramphus chloris) with $10.11 \%$ relative abundance recorded for each species (Table 1). These three dominating species comprises of three different families namely Pycnonotidae, Columbidae and Alcedinidae. Meanwhile, species such as Chestnut-collared Kingfisher (Actenoides concretus), Emerald Dove (Chalcophaps indica), Spotted Dove (Streptopelia chinensis), Eastern Crimson Sunbird (Aethopyga siparaja), Pied-triller (Lalage nigra), Brown-capped Woodpecker (Dendrocopus molusccencis), Asian Glossy Starling (Aplonis panayensis), Savanna Nightjar (Caprimulgus affinis), Yellow-bellied Prinia (Prinia flaviventris), Orange-bellied Flowerpecker (Dicaeum trigonostigma) and White-breasted Woodswallow (Artamus leucorhynchus) were all recorded in singleton.

On the contrary, unlike in NRAF the three most abundance species recorded in the FDIST were all came from the same family that is the Pycnonotidae family. The Yellow-vented Bulbul (Pycnonotus goiavier) recorded the highest with $25 \%$ relative abundance followed by Olivewinged Bulbul (Pycnonotus plumosus) and Red-eyed Bulbul (Pycnonotus brunneus) with 13\% abundance recorded in each species as shown in Table 1.Species such as Striped Tit Babbler (Macronous gularis), Olive-backed Sunbird (Nectarinia jugularis), Chestnut Munia (Lonchura atricapilla), Rufous piculet (Sasia abnormis), Asian Glossy Starling (Aplonis panayensis), Brown Shrike (Lanius cristatus cristatus), Mangrove Whistler (Pachycephala grisola), Bornean Brown Barbet (Calorhamphus fuliginosus tertius) and Reddish Scops Owl (Otus rufescens) were all recorded in singleton in this type of forest. 
Table 1. Species Assemblage of Understory Birds Recorded in NRAF and FDIST

\begin{tabular}{|c|c|c|c|c|c|c|}
\hline \multirow{2}{*}{ Family/ Species } & \multicolumn{2}{|c|}{ Mist-netted } & \multicolumn{3}{|c|}{ Conservation Status } & \multirow[t]{2}{*}{ Guild } \\
\hline & NRAF & FDIST & Residential & WCE & IUCN & \\
\hline \multicolumn{7}{|l|}{ Pycnonotidae } \\
\hline $\begin{array}{l}\text { Red-eyed } \quad \text { Bulbul } \quad \text { (Pycnonotus } \\
\text { brunneus) }\end{array}$ & 7 & 9 & Resident & - & LC & $\mathrm{F}, \mathrm{I}$ \\
\hline $\begin{array}{l}\text { Yellow-vented Bulbul (Pycnonotus } \\
\text { goiavier) }\end{array}$ & 14 & 18 & Resident & - & $\mathrm{LC}$ & $\mathrm{F}, \mathrm{I}$ \\
\hline $\begin{array}{l}\text { Olive-winged Bulbul } \quad \text { (Pycnonotus } \\
\text { plumosus) }\end{array}$ & o & 9 & Resident & - & $\mathrm{LC}$ & $\mathrm{F}, \mathrm{I}$ \\
\hline \multicolumn{7}{|l|}{ Alcedinidae } \\
\hline $\begin{array}{ll}\text { Blue-eared } & \text { Kingfisher } \\
\text { (Alcedomeninting) } & \end{array}$ & 3 & 2 & Resident & - & LC & $\mathrm{C}$ \\
\hline $\begin{array}{l}\text { Chestnut-collared Kingfisher } \\
\text { (Actenoides concretus) }\end{array}$ & 1 & o & $\begin{array}{l}\text { Scare } \\
\text { resident }\end{array}$ & - & NT & $\mathrm{C}, \mathrm{I}$ \\
\hline $\begin{array}{l}\text { Collared Kingfisher (Todiramphus } \\
\text { chloris) }\end{array}$ & 9 & 4 & Resident & - & LC & I \\
\hline \multicolumn{7}{|l|}{ Columbidae } \\
\hline Emerald Dove (Chalcophaps indica) & 1 & 2 & $\begin{array}{l}\text { Nomadic } \\
\text { resident }\end{array}$ & $\mathrm{P}$ & $\mathrm{LC}$ & $\mathrm{F}, \mathrm{G}$ \\
\hline Spotted Dove (Streptopelia chinensis) & 1 & o & Resident & - & - & G \\
\hline Zebra Dove (Geopelia striata) & 9 & o & Resident & - & $\mathrm{LC}$ & $\mathrm{G}, \mathrm{I}$ \\
\hline \multicolumn{7}{|l|}{ Timaliidae } \\
\hline $\begin{array}{l}\text { Bold-Striped Tit- Babbler } \\
\text { (Macronousbornensisbornensis) }\end{array}$ & 7 & 6 & Resident & - & LC & I \\
\hline $\begin{array}{l}\text { Striped Tit Babbler (Macronous } \\
\text { gularis) }\end{array}$ & o & 1 & - & - & LC & I \\
\hline $\begin{array}{l}\text { Rhipiduridae } \\
\text { Pied Fantail } \\
\text { (Rhipidurajavanica) }\end{array}$ & 7 & 4 & Resident & - & LC & I \\
\hline \multicolumn{7}{|l|}{ Nectariniidae } \\
\hline $\begin{array}{l}\text { Brown-throated Sunbird } \\
\text { (Anthreptesmalacencis) }\end{array}$ & 6 & o & Resident & - & LC & $\begin{array}{c}\mathrm{N}, \mathrm{I}, \\
\mathrm{F}\end{array}$ \\
\hline $\begin{array}{l}\text { Eastern Crimson Sunbird (Aethopyga } \\
\text { siparaja) }\end{array}$ & 1 & o & $\begin{array}{l}\text { Lowland } \\
\text { resident }\end{array}$ & - & LC & $\mathrm{N}, \mathrm{I}$ \\
\hline $\begin{array}{l}\text { Little Spider Hunter } \\
\text { (Arachnotheralongirostra) }\end{array}$ & o & 2 & Resident & - & LC & $\mathrm{N}, \mathrm{I}$ \\
\hline $\begin{array}{l}\text { Olive-backed Sunbird (Nectarinia } \\
\text { jugularis) }\end{array}$ & 0 & 1 & Resident & - & $\mathrm{LC}$ & $\mathrm{N}, \mathrm{I}$ \\
\hline \multicolumn{7}{|l|}{ Alauididae } \\
\hline $\begin{array}{l}\text { Eurasian Tree Sparrow (Passer } \\
\text { montanus) }\end{array}$ & 6 & o & Resident & - & LC & G \\
\hline \multicolumn{7}{|l|}{ Estrildidae } \\
\hline $\begin{array}{lll}\text { Chestnut } & \text { Munia } & \text { (Lonchura } \\
\text { atricapilla) } & & \end{array}$ & 3 & 1 & Resident & - & $\mathrm{LC}$ & G \\
\hline Dusky Munia (Lonchurafuscans) & 2 & o & $\begin{array}{l}\text { Lowland } \\
\text { endemic }\end{array}$ & - & LC & G \\
\hline
\end{tabular}




\section{Campephagidae}

Black-winged Flycatcher-shrike

(Hemipushirundinaceus)

Pied-triller (Lalage nigra)

\section{Apodidae}

Glossy Swiftlet (Collocaliaesculenta)

\section{Aegithinidae}

Common Iora (Aegithinatiphia)

Picidae

Brown-capped Woodpecker

(Dendrocopus molusccencis)

Rufous piculet (Sasia abnormis)

Sturnidae

Asian Glossy Starling (Aplonis

panayensis)

Caprimulgidae

Savanna Nightjar (Caprimulgus

affinis)

Cisticolidae

Yellow-bellied

Prinia

(Prinia

flaviventris

Dicaeidae

Orange-bellied Flowerpecker

(Dicaeum trigonostigma)

\section{Hirundinidae}

White-breasted Woodswallow

(Artamus leucorhynchus)

Laniidae

Brown Shrike (Lanius cristatus cristatus)

Pachycephalidae

Mangrove Whistler (Pachycephala grisola)

\section{Rhampastidae}

Bornean Brown Barbet

(Calorhamphus fuliginosus tertius)

\section{Strigidae}

Reddish Scops Owl (Otus rufescens)
3

1

2

o

1
Resident

Resident

Resident

Resident

Resident

Resident

Resident

Resident

O

Resident

Resident

O

Resident

LC

I

Scarce

winter

visitor

Resident

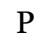

LC

o

Resident

LC

F

Scarce

$\mathrm{P} \quad \mathrm{NT}$

I

\section{Total}

\section{9} 72

* $\overline{\mathrm{WCE}}=$ Sabah Wildlife Conservation Enactment, 1997, IUCN= International Union Conservation of Nature, LC $=$ Least Concern, NT= Near Threatened, $\mathrm{C}=$ Carnivore, $\mathrm{F}=$ Frugivore, $\mathrm{I}=$ Insectivore, $\mathrm{G}=$ Granivore, $\mathrm{N}=$ Nectarivore

The finding from this study showed that in NRAF there was $56 \%$ of the bird species accounted as having more than one feeding guild. In addition, $27 \%$ of birds were insectivores and $14 \%$ were granivorous birds. Similarly, birds having more than one feeding guilds were found to be dominant in FDIST with $58 \%$ relative abundance. 
Meanwhile, $36 \%$ were accounted as insectivorous birds in this type of forest.

The study shows that both forest types were dominated by the Pycnonotidae family of which indicates that they provide sufficient food such fruits and insects. The feeding guilds of this family are frugivore and insectivore (Azman, 2011). The three most abundance species present in the NRAF (yellow vented bulbul, collared kingfisher and zebra dove) were from different families as opposed to FDIST, of which the three most abundant species came Pycnonotidae family. The species found in NRAF and FDIST were commonly found in cultivated areas and secondary forest (Wong 2012).

To date, there were only a few studies done that measure the diversity of bird population in Acacia plantation such as (Sheldon et al., 2010) and (Styring et al., 2011) of which being documented south-east of Sabah. Meanwhile Sompud et al. (2014) has conducted a preliminary survey in one part of the NRAF inside the Universiti Malaysia Sabah campus. The Shannon-Wiener index showed that both NRAF and FDIST have high diversity of bird population as their value falls within the range of 1.5 to 3.5 (Magurran, 2004). Interestingly, there was no significant difference of bird diversity between these two types of forests. The results for Mann-Whitney $U$ test also shows that there was no significant different between NRAF and FDIST in terms of the number of birds recorded from those to forests. Therefore, it suggests that by NRAF does support bird population.

There was less than $30 \%$ of species similarity of birds that were found between these two forests. Thus, this indicates that both of these forests are important in supporting the diversity of different species of birds. Interestingly, one lowland endemic species namely Dusky Munia (Lonchurafuscans) and a scarce resident species that is the Chestnut-collared Kingfisher (Actenoides concretus) based on (Phillips \& Phillips, 2011) were able to be recorded in NRAF. Furthermore, the Chestnut-collared Kingfisher (Actenoides concretus) is also classified as a Near Threatened species based on (IUCN, 2018). The presence of these species of birds does shed some lights that these species are able to survive in Acacia dominated habitat. In addition, the Emerald dove (Chalcophaps indica) that was classified as protected species under the (WCE, 1997) was recorded in both NRAF and FDIST. Hence, it indicates that NRAF does play an equally significant role as the FDIST in supporting the biodiversity of bird population. Due to these results, the null hypothesis was rejected because the birds recorded in NRAF were as diversity and abundant as those at FDIST. Therefore, it is important to conserve these Acacia forest islands inside the campus for biodiversity conservation.

\section{CONCLUSION}

This study shows that Naturally Regenerated Acacia Forest support bird population in terms of diversity and abundance. It is recommended that further study needed to be done at NRAF to understand in depth about the function of this type of forest. Furthermore, this type of forest should be conserved for the conservation and research purposes.

\section{ACKNOWLEDGEMENT}

We would like to express our gratitude to the UMS SLB grant (SLBoo61-STWN-2013) and SBKo424-2018for the funds that have enabled us to conduct our research. We would also like to thank our UMS students for their volunteering work in helping us during the survey. 


\section{REFERENCES}

Azman, N. M., N. S. A. Latip, S. A. M. Sah, M. A. M. Akil, N. J. Shafie\& N. L. Khairuddin. 2011, Avian diversity and feeding guilds in a secondary forest, an oil palm plantation and a paddy field riparian area of the Kerian river basin, Perak, Malaysia. Journal of Tropical Life Science Research22(2): 45-64.

Clearly, D. F. R., T. J. B. Boyle, T. Setiyawati, C. D. Anggraeni, E. E. V. Loon, \& S. B. J, Menken. 2007, Bird species and traits associated with logged and unlogged forest in Borneo. Journal of Ecological Application 17(4): 1184-1197.

Edwards, D. P., F. A. Ansell, A. H. Ahmad, R. Nilus \& K. C. Hamer. 2009, The value of rehabilitating logged rainforest for birds. Journal of Conservation Biology 23(6): 16281633 .

Hartley, M. J. 2002, Rationale and methods for conserving biodiversity in plantation forest. Journal of Forest Ecology and Management 155: 81-95.

IUCN. 2018, The IUCN Red List of Threatened Species 2018. (http;//www.iucnredlist.org). Accessed on $30^{\text {th }}$ October 2018.

Lambert, F. R. \& N. J. Collar. 2002, The future for sundaic lowland forest birds: long-term effect of commercial logging and fragmentation. Forktail 18: 127-146.

Loiselle, B. A. \& J. G. Blake. 1999, Dispersal of melastome seeds by fruit-eating birds of tropical forest understory. Journal of Ecology 80(1): 330-336.

Magurran, A. E., 2004, Measuring biological diversity. Blackwell Publishing, Oxford.

Phillips Q. and K. Phillips. 2011, Birds of Borneo. John Beaufoy Publishing Ltd., Oxford.

Peh, K.S.-H., J. Jong, N.S. Sodhi, L. H. Lim \& A. M. Yap. 2005, Lowland rainforest avifauna and human disturbance: persistence of primary forest birds in selectively logged forests and mixed-rural habitats

Sheldon, F. H., A. Styring \& P.A. Hosner. 2010, Bird species richness in a Bornean exotic tree plantation: a long-term perspective. Journal of Biological Conservation 143: 399407.

Sodhi, N.S., P.K. Lian, D. M. Prawiradilaga, I. Tinulele, D. D. Putra, \& T.T. Han. 2005, Land use and conservation value for forest birds in Central Sulawesi (Indonesia). Journal of Biological Conservation 122: 547-558.

Sompud, J., A. R. Mojiol, E. A. Gilbert \& M. Amir. 2014, The preliminary survey of the understory birds in UMS campus. International Conference of Borneo Research Council, 5-7, August 2014. Universiti Malaysia Sabah, Kota Kinabalu. DOI:10.13140/2.1.2808.6085

Styring, A., R. Ragai, U. Joanes, R. Stuebing, P.A. Hosner, \& F.H. Sheldon. 2011, Bird community assembly in Bornean industrial tree plantations: effect of forest age and structure. Journal of Forest Ecology and Management261: 531-544.

Thomas, K.I. \& G.A. Kent. 1987, Research on Acacia mangium in Sabah: a review. In Turnbull, J.W. Australian acacias in developing countries: proceedings of an international workshop, 4 -7 August 1986, Gympie, Queensland. ACIAR Proceedings 16: 160-163.

Udarbe, M.P. \& A. J. Hepburn. 1987, Development of Acacia mangium as a Plantation Species in Sabah. In Turnbull, J.W. (ed.) Australian acacias in developing countries: proceedings of an international workshop, 4 -7 August 1986. Gympie, Queensland, ACIAR Proceedings 16: 157159.

WCE, 1997. Sabah Wildlife Conservation Enactment No. 6 of 1997, Sabah Government Printing, Kota Kinabalu.

Wong, T. S. 2012, A Naturalist's guide to the birds of Borneo: Sabah, Sarawak, Brunei and Kalimantan. Oxford, John Beaufoy Publishing Ltd., Oxford.

Yap, C. A-M., N.S. Sodhi, \& K.S.-H. Peh. 2007, Phenology of tropical birds in peninsular Malaysia: effects of selective logging and food resources. The Auk 124(3): 945-961.

Zakaria, M., L. Chong \& M. E. Yusuf. 2005, Comparison of species composition in three forest types: towards using bird as indicator of forest ecosystem health. Journal of Biological Sciences 5(6): 734-737. 